\title{
Learning Philosophy in the 21 st Century
}

\author{
Abdul Jaleel K. Alwali \\ CHSS United Arab Emirates University
}

\begin{abstract}
This study will answer the question: What do students expect to learn from philosophy teachers in the 21 st century? By framing a response based on the researcher's teaching philosophy developed over 30 years, a survey conducted of UAEU students, a discussion of the changing role and purpose of philosophy in the academy, and current pedagogical philosophy in teaching. The study has also focused on how philosophical questions have been changed over time, what are the characteristics of philosophy teachers and students, the new direction for teaching philosophy, using new technology to teach philosophy, and career opportunities. The practical frame of this research will be analyzed students survey conducted on female students from United Arab Emirates University. The author will use the method of content analysis to investigate and trace this phenomenon to determine its meaning, and the new direction for teaching philosophy, therefore the approach of the research would be analysis and synthesis.
\end{abstract}

Keywords: philosophical questions, characteristics, goals of teaching philosophy, career opportunities, students survey

\section{Methodology}

The research design comprises two basic aspects, namely, the theoretical frame and the applied practical research.

In the theoretical frame, I will rely on the literature of describing the phenomenon of teaching philosophy referring to discussions of the changing role and purpose of philosophy in the academy and current pedagogical philosophy in teaching to be undertaken as a guide for such description.

The practical frame, on the other hand, will be analyzed students survey conducted on female students from United Arab Emirates University to know their age, education level, father \& mother's education and their work, philosophy courses level, how different teachers at university and college levels teach philosophy, and what the students expect to learn from philosophy teachers.

Therefore, the approach of the research would be analysis and synthesis.

The result of this method is produced two academic tasks, a paper presented at the 12th International Conference on Philosophy in Athens, Greece, on 22-25 May, 2017 organized by Athens Institute for Education and Research ATINER. And the individual paper will be published on the journal.

\section{Introduction}

What do students expect to learn from philosophy teachers in the 21 st century?

Abdul Jaleel K. Alwali, Prof., Dr., Department of Philosophy, CHSS United Arab Emirates University, Al Ain Abu Dhabi, UAE; main research field: Ancient Greek Philosophy, Value Theory, and Intercultural Philosophy. 
This study will answer this question by framing a response based on the following:

(1) The researcher's teaching philosophy developed over 30 years, in many different universities around the world.

(2) A survey conducted of UAEU students whom the researcher is currently teaching philosophy.

(3) A discussion of the changing role and purpose of philosophy in the academy and current pedagogical philosophy in teaching.

Traditionally, the researcher taught theoretical philosophy. The objective of this was not for students to use philosophy itself, but for them to gain knowledge rather than skills. All philosophy students need to understand who key philosophers are and what their philosophy is. Plato, Aristotle, Descartes, Al-Farabi, John Dewey attracted former generations of students, who desired to know about and appreciate their philosophy. This traditional method of teaching philosophy used the Socratic Method to memorize and recall information in order to assess student learning (Plato 2015).

Why did the students in the past focus just on acquiring knowledge?

In the past, there were limited resources for obtaining information about philosophy and philosophers. Classes were the main sources of information and otherwise there was a general lack of access to data. Historically, there were very few local channels, limited hard copies of newspapers, magazines and journals which were also not available to all students, so the classes were expected to be rich sources of information. Educated people were also evaluated according to their knowledge rather than their skills.

\section{Philosophical Questions}

Philosophical questions have changed over time. Thales (Miletus 624-546BC) asked the first metaphysical question, "what is the primary principle of the world?" (O'Grady n.d.) He rejected the traditional explanation of the world's origin: instead of building his answer on ideas about mythology, he also began a rational inquiry stating that the origin of all matter is water (Aristotle 1989).

The value of Thales's question is not in answering the question itself but in undertaking the philosophical inquiry.

Pythagoras of Samos (582-504BC) (Burkert 1972) made a connection between philosophy and practical life, defining philosophy as "the love of wisdom" ("Pythagoras", 2017). Thus, it is possible to assert that the Ancient Greek philosophers asked the most fundamental questions about human beings and their relationship to the world.

The central traditional philosophical questions were:

What is the goal of it all? What is knowledge? Do we have "free will"? Are ethical values relative or absolute? What is truth? How can we be happy? What is the meaning of life?

What is a good life (Mahant 2013)?

These questions have since evolved in reference to contemporary philosophical issues. In his lectures, Stanford philosopher John Perry, amongst others (Perry 2010), suggested the following philosophical issues and questions:

A. Issue: Global justice. Q: What new principles of justice will help us manage distinctively 21 st century problems?

B. Issue: Humans and the environment. Q: What relationship should humans have to the environment?

C. Issue: The rise of cloning. Q: What is a person? 
D. Issue: New models of collective decision making and collective rationality. Q: Can philosophers help build them in time to guide us in meeting the challenges of this century?

E. Issue: Intellectual property. Q: Can the very idea of intellectual property survive in the age of re-mix?

F. Issue: Information and misinformation in the information age. Q: How can we distinguish the good from the bad, the wheat from the chaff?

G. Issue: Science. Q: Can freedom survive the onslaught of science?

H. Issue: The mind-body problem. Q: Neuroscience is revealing so much about the brain. Does this new knowledge solve age-old mysteries of the mind?

I. Issue: Finding a new basis for common sensibilities and common values. Q: Can we find a new basis for shared values that will bring us together rather than tear us apart? (Perry 2010)

\section{Using a New Technology to Teach Philosophy}

The internet has become a vital tool for students, while smartphones, laptops, and satellite television have contributed to a plethora of information hubs. Research shows: "The generation of American kids (aged 3 to 18) is the tech-savviest in history: $27 \%$ of them use tablets, $43 \%$ use smartphones, and $52 \%$ use laptops. Los Angeles County alone spent $\$ 30$ million on classroom iPads this year, outfitting 640,000 kids by late 2014" (The College Board 2016, 620)

Various types of technologies are being used in classrooms, such as:

- Computers,

- The creation of class websites and blogs,

- Digital microphones,

- Mobile devices,

- Smart interactive Whiteboards,

- Online media,

- Online study tools.

As a result, new methods of teaching philosophy have emerged utilizing these technologies. The internet is used as a point of contact for students when selecting their majors, enrolling in courses, receiving education materials, submitting assignments, and completing administrative tasks. It saves time and establishes the world as a global village. One of the key advantages offered by the Internet is making information available to people around the world; individuals simply need a computer or smartphone and Internet access, and can then obtain whatever information they require.

Distance education is a unique example of using the Internet for education. "Distance education or distance learning is the education of students who may not always be physically present at a school. Courses that are conducted (51\% or more) are either hybrid, blended or $100 \%$ whole instruction" ("Distance education," 2017). Students are able to receive most of their education without physically attending a classroom.

\section{Characteristics of Philosophy Teachers}

Teachers of philosophy should possess the following characteristics:
A. Flexibility,
B. Respect for students,
C. Willingness to listen,
D. Creates a sense of community and belonging in the classroom,
E. Enthusiasm and compassion,
F. Love of learning, 
G. Leadership skills,

H. Ability to collaborate with colleagues on an ongoing basis,

I. Maintain professionalism in all areas. (Orlando 2013)

\section{Characteristics of Philosophy Students}

Philosophy students should possess the specific attributes required to study philosophy. The study of philosophy differs from other subjects: It requires an ability to understand and analyze philosophical texts. Tutors have listed some of the skills and qualities they regard as important when considering an application from an individual wanting to study philosophy:
A. Intellectual curiosity,
B. Intellectual independence,
C. Critical intelligence,
D. Commitment,
E. Communication and study skills. (University of Southampton 2013)

There are clear differences between these contemporary philosophy characteristics comparing with classical ones, as Al-Farabi stated several rules for the effective teaching of philosophy to youths, including:

- Knowledge of the natural sciences.

- Mathematics is an important subject in training the mind of the young philosopher.

- The study of logic is of great educational value before commencing the study of philosophy.

- The student should concentrate his attention upon the object of study, and make a success of it. (Al-Farabi 1987, 224)

\section{Goals of Teaching Philosophy.}

Skills have become a new phenomenon, and the main goal of learning philosophy is primarily focused on acquiring skills such as critical thinking, creativity, collaboration, and problem-solving.

The newly identified skills for teaching philosophy are:

A. Developing and supporting beliefs,

B. Evaluating the strength of arguments made by others in real-life situations,

C. Applying the strategies to understanding current issues,

D. The ability to summarize, to consider context, to devise independent theories, and to develop reasonable conclusions.

Today, philosophy students read, discuss, and critically examine problems and issues in the field of philosophy and cross-disciplinary aspects of philosophy. This is because not only need to understand philosophy, they are also - more importantly — expected to use philosophy as a handbook of life learning skills. For example, a business student may study aspects of philosophy in terms of their practical application for managing a group of people or a corporation, or they may study philosophy from the perspective of implementing ethics in the workplace.

To achieve a new direction for teaching philosophy, it is crucial to consider the following:

A. Providing students with specific knowledge of the central areas of philosophy, including logic, value theory, history of philosophy, political philosophy, metaphysics, and epistemology,

B. Increasing the role of digital technology in all philosophy courses, 
C. Training students in logical analysis and reasoned argument,

D. Educating students in creative problem solving outside the square,

E. Equipping students with advanced skills in research, reading, writing, listening, and speaking,

F. Instilling a lifelong love of learning.

\section{Career Opportunities}

There are some specific career opportunities for those with good degrees in philosophy include: professor, journalist, editor, policy developer (in government and non-government organizations), paralegal specialist, environmental manager, ethicist (in health systems, corporations, and research organizations), author, researcher, technical writer, philosophical counsellor, software designer (applying logic to object-oriented programming), or diplomat.

\section{Students Survey}

The results of the students' surveys on learning philosophy in the 21st century showing:

Question 1: Gender?

This survey was conducted on 48 female students from United Arab Emirates University.

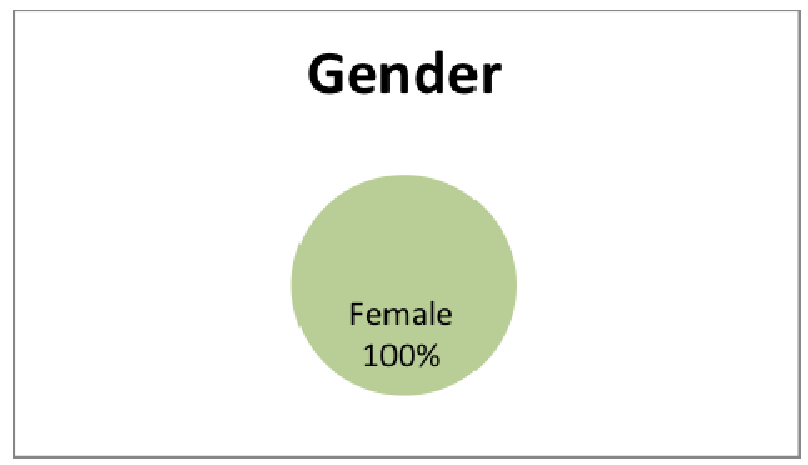

Question 2: Age?

The pie chart below shows the percentage of respondents in each age group. 25 students (52\%) were less than 20 years old, while 23 students (48\%) were between 20 and 30 years old.

\begin{tabular}{|c|c|c|c|}
\hline \multirow{3}{*}{$\begin{array}{c}20-30 \\
48 \%\end{array}$} & \multirow{3}{*}{$\begin{array}{c}\text { Less than } \\
20 \\
52 \%\end{array}$} & Age & Number of students \\
\hline & & Less than 20 & 25 \\
\hline & & $20-30$ & 23 \\
\hline
\end{tabular}

Question 3: Country?

The pie chart below represents the respondents' countries of origin. 42 participants (87\%) are from the United Arab Emirates, while 6 participants (13\%) are from other countries, such as Syria and Pakistan. 


\begin{tabular}{|c|c|c|c|}
\hline \multirow{3}{*}{$\begin{array}{c}\text { Other } \\
\text { Countries } \\
13 \%\end{array}$} & Country & Country & Number of students \\
\hline & & UAE & 42 \\
\hline & & Other Countries & 6 \\
\hline
\end{tabular}

Question 4: Education level?

The survey was undertaken by university students.

\section{Education level}

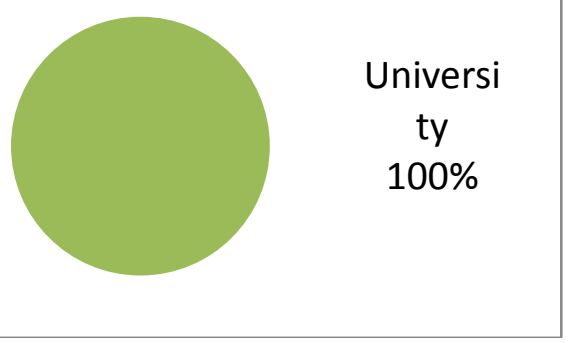

Question 5: Father's education?

The pie chart below presents the levels of education achieved by respondents' fathers. The highest numbers are $15(31 \%)$ for high school and $13(27 \%)$ for university education, while the lowest is $3(6 \%)$ for both postgraduate and primary school educations.

\begin{tabular}{|c|c|c|}
\hline Father's Education & Father's education & Number of students \\
\hline Post & Illiterate & 5 \\
\hline $\begin{array}{c}\text { Gradua } \\
\quad 6 \%\end{array}$ & Primary School & 3 \\
\hline University & Secondary School & 9 \\
\hline & High School & 15 \\
\hline $\begin{array}{l}\text { secondary } \\
\text { School }\end{array}$ & University & 13 \\
\hline $31 \%$ & Postgraduate & 3 \\
\hline
\end{tabular}

Question 6: Mother's education?

The pie chart below shows the percentages gathered from the survey with regard to the level of education reached by the respondents' mothers. The highest percentage is $35 \%$ for university followed by $23 \%$ for high school, while the lowest is $10 \%$ for illiterate. 


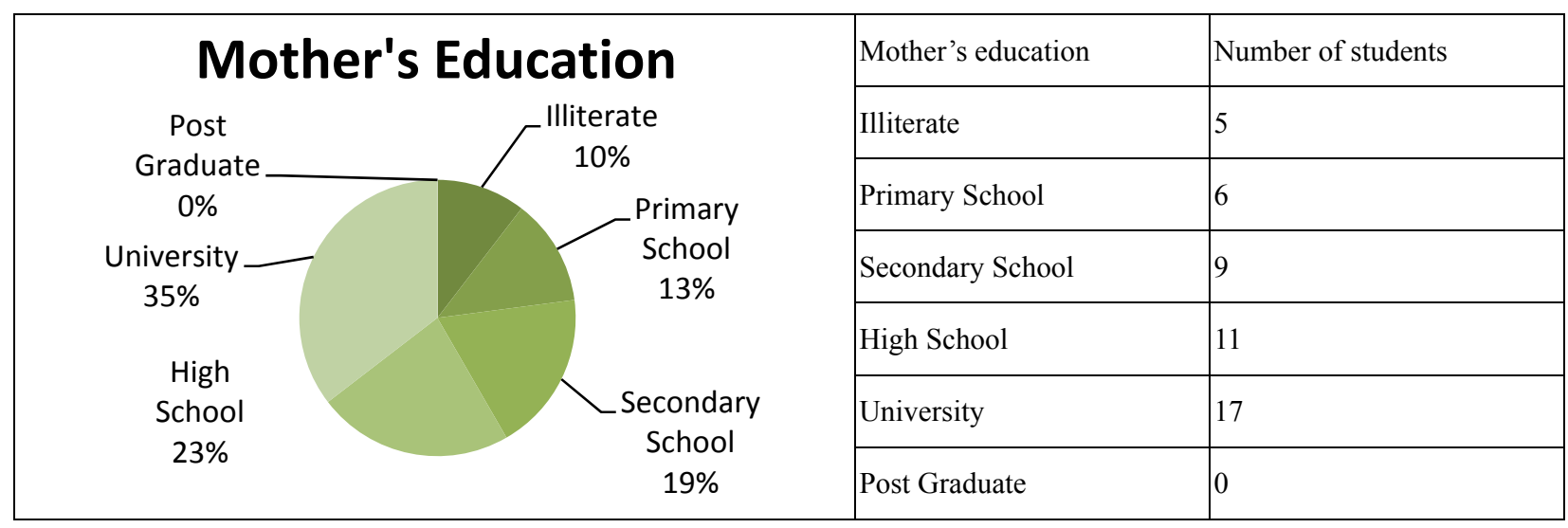

Question 7: Father's work?

The pie chart below shows the percentages gathered from the survey with regard to the range of jobs held by the respondents' fathers. The results show that a high percentage (29\%) of fathers is retired/not working. The second highest is $23 \%$ for police officers. Business and military are similar, with a percentage of $13 \%$ and $15 \%$ respectively. There are also a range of other jobs, such as teachers, fire fighters, and administrators.

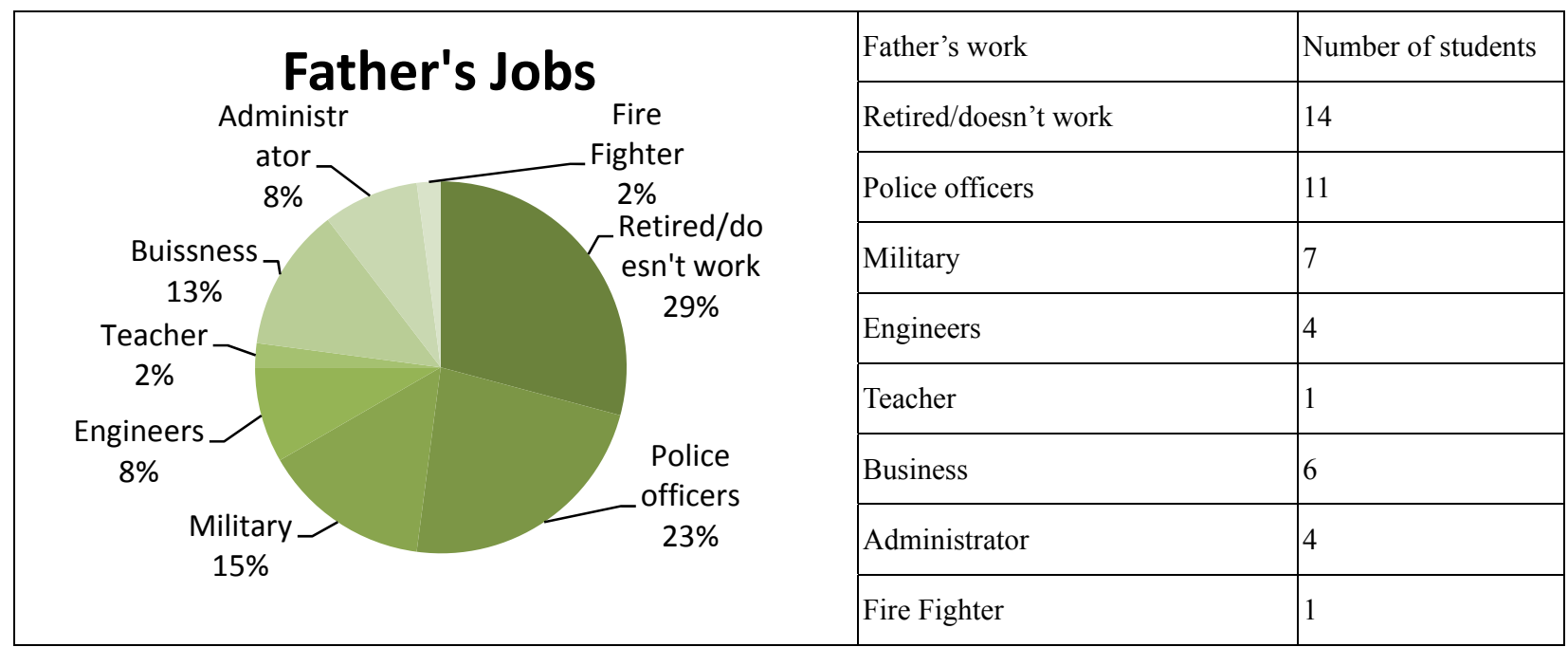

Question 8: Mother's work?

The pie chart below shows the percentages collated from the survey with regard to the range of jobs held by the respondents' mothers. The results show that the majority (69\%) of mothers are housewives. The second highest percentage (15\%) refers to teachers, followed by governmental work $(10 \%)$. The lowest percentages are for other jobs, such as translators and administrators. 


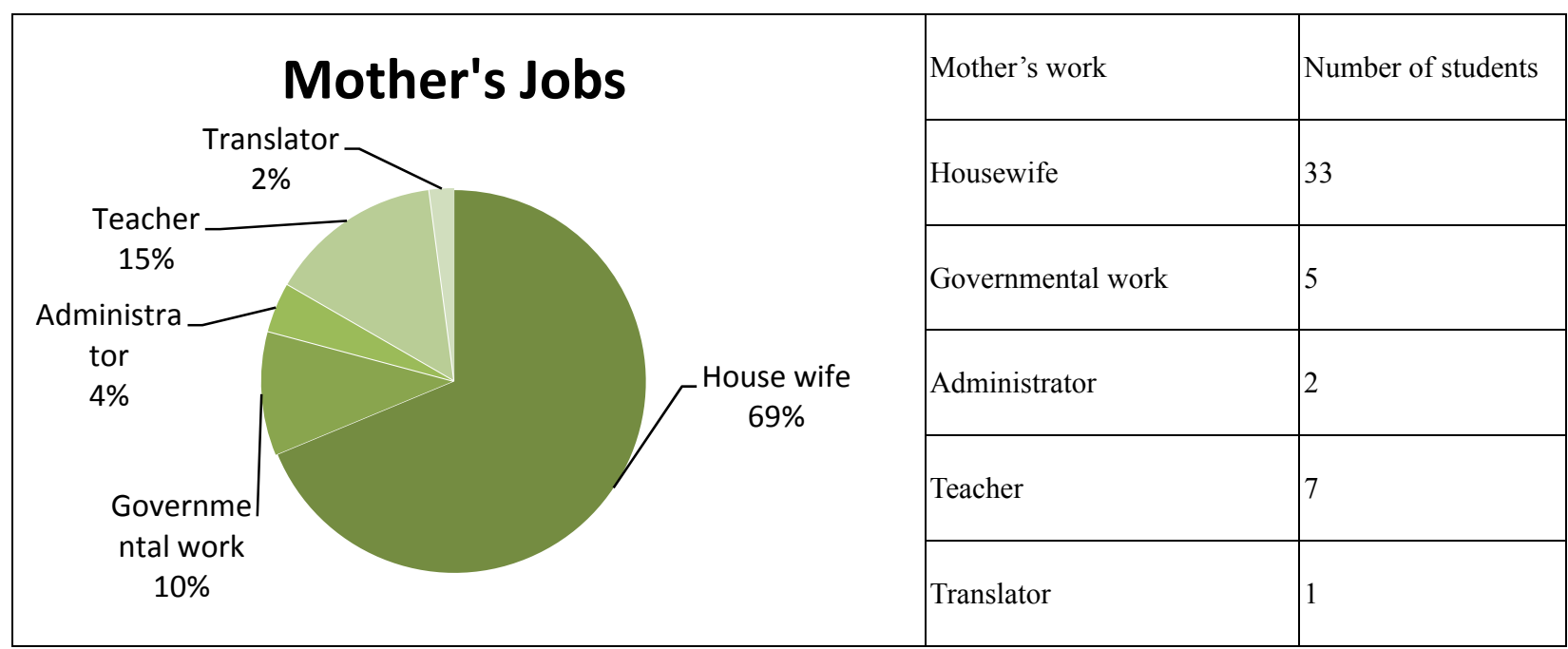

Question 9: Do you study philosophy courses in general education or other programmes? If yes, what are they? In response to question nine of the survey, 44 out of the 48 students (92\%) stated that their knowledge of philosophy comes from general education courses (this is a band of courses which students elect to study based on their interests). Such courses include: introduction to philosophy, the principle of professional ethics, critical thinking, and human rights. Other respondents stated that philosophy is a component of some courses in their area of specialization.

\begin{tabular}{|c|c|c|}
\hline \multirow{3}{*}{$\begin{array}{l}\text { Sources of Philosophy } \\
\text { Knowledge } \\
\text { Other } \\
\text { sources } \\
8 \% \\
\\
\text { General } \\
\text { Education } \\
92 \%\end{array}$} & Source of philosophy & Number of students \\
\hline & General Education & 44 \\
\hline & Other sources & 4 \\
\hline
\end{tabular}

Question 10: How do different teachers at university and college levels teach philosophy?

The answers to this question indicate that philosophy is being taught using different techniques and methods. In total, $31 \%$ of students described how their professors use personal skills when teaching, such as choosing to talk about a small part of philosophy or going into specific areas of philosophy in depth. Using technology like presentations ranks second (15\%), followed by debates through discussing case studies from articles $(6 \%)$, and giving examples from practical life $(8 \%)$. The smallest percentage is $2 \%$ for books. $38 \%$ of the students had no answer for this question, with many explaining that this is the first philosophy course they have taken. 


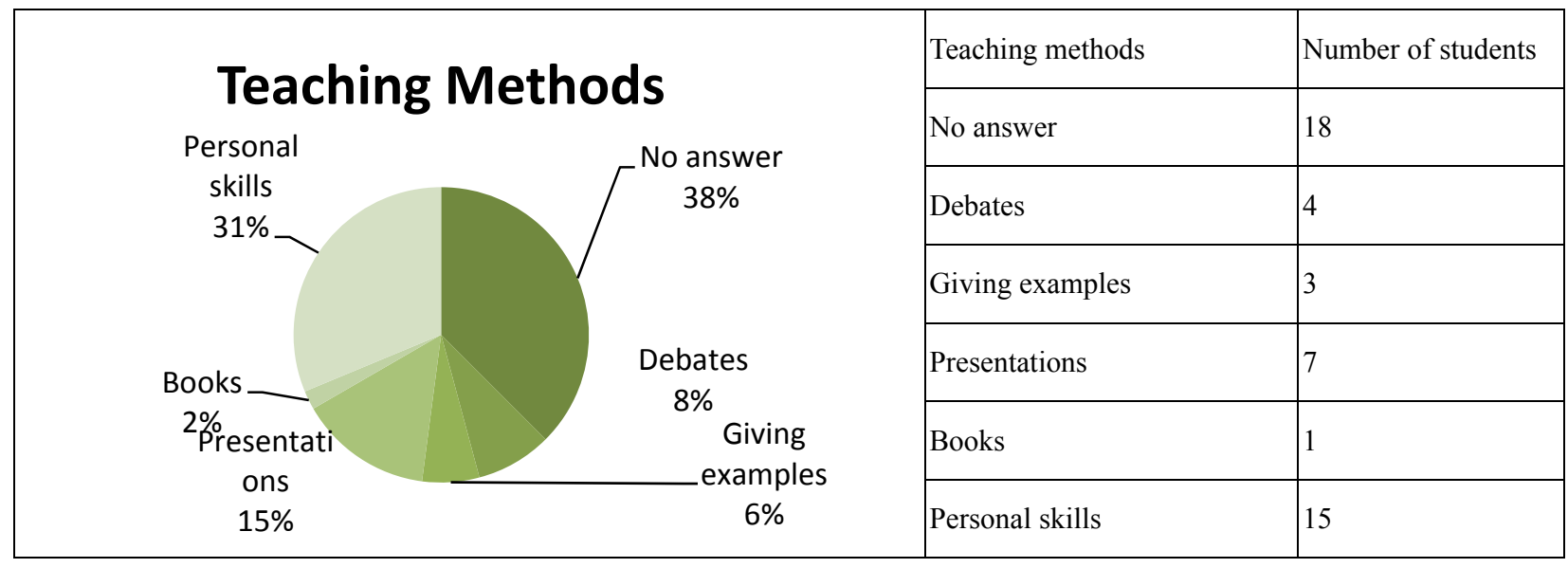

Question 11: What do the students expect to learn from philosophy teachers?

The pie chart below shows the percentages gathered from the survey with regard to what the respondents expect to learn from their philosophy teachers. The answers show that most of the participants (37\%) are expecting to learn about the "history of philosophy, philosophers and ethics," while $25 \%$ expect to learn about life skills, and $17 \%$ are hoping to gain critical thinking skills from their study of philosophy. Just four participants $(8 \%)$ were expecting to learn about theories and interesting facts.

It is important to note that $13 \%$ of the respondents had no answer to this question.

\begin{tabular}{|c|c|c|c|}
\hline & & Learning expectations & Number of students \\
\hline \multirow{5}{*}{$\begin{array}{l}\text { Theories } \\
\text { and } \\
\text { interesting } \\
\text { facts } \\
\text { answ\&\% } \\
13 \%\end{array}$} & \multirow{2}{*}{$\begin{array}{c}\text { Life skills } \\
25 \%\end{array}$} & Life skills & 12 \\
\hline & & $\begin{array}{l}\text { History of philosophy, } \\
\text { philosophers and ethics }\end{array}$ & 18 \\
\hline & \multirow{3}{*}{$\begin{array}{l}\text { History of } \\
\text { philosophy } \\
\text {,philosophe } \\
\text { rs and } \\
\text { Ethics } \\
37 \%\end{array}$} & Thinking skills & 8 \\
\hline & & Theories and interesting facts & 4 \\
\hline & & No answer & 6 \\
\hline
\end{tabular}

\section{Works Cited}

Al-Farabi, A. (1987). Risālat al-Tanbih 'alī sabil al-Sa'āda. Investigated by Khalifat, S., University of Jordan, Amman.

Aristotle. Metaphysics, 983b21-22, Aristotle in 23 Volumes, Vols.17, 18. Trans. Hugh Tredennick. Cambridge, MA: Harvard

University Press; London: William Heinemann Ltd., 1989. Accessed: 23 December 2017. $<$ http://www.perseus.tufts.edu/hopper/text?doc=Perseus\%3Atext\%3A1999.01.0052\%3Abook\%3D1\%3Asection\%3D983b>. Burkert, W. Lore and Science in Early Pythagoreanism. Trans. E. L. Minar. Cambridge, Mass.: Harvard University Press, 1972. Dwyer, M. Critical Thinking. Accessed: 22 December 2017. <https://criticalthinking-mc205.wikispaces.com/Course+Syllabus $>$. “Distance Education.” Wikipedia. Accessed: 22 December 2017. <https://en.wikipedia.org/wiki/Distance_education>. 
Mahant, N. What Are the Top 10 Big Philosophical Questions Most People Wonder About? 2013. Accessed: 22 December 2017. $<$ https://www.quora.com/What-are-the-top-10-big-philosophical-questions-most-people-wonder-about $>$.

Orlando, M. Nine Characteristics of a Great Teacher. 2013. Accessed: 22 December 2017. $<$ https://www.facultyfocus.com/articles/philosophy-of-teaching/nine-characteristics-of-a-great-teacher/>.

O' Grady, P. Thales of Miletus (c. 620 B.C.E.—C. 546 B.C.E.). n.d. Accessed: 22 December 2017. $<$ http://www.iep.utm.edu/thales/\#H3>.

Plato. Theaetetus. London and New York: John M. 2015. $<$ http://eltalondeaquiles.pucp.edu.pe/wp-content/uploads/2016/02/Routledge-Library-Editions_-Epistemology-John-M--Coo per-Platos-Theaetetus-Routledge-2015.pdf $>$.

"Pythagoras." Wikiquote. Accessed: 22 December 2017. <https://en.wikiquote.org/wiki/Pythagoras>.

Perry. J., et al. Ten Philosophical-Issues of the 21st Century. 2010. $<$ https://neouto.wordpress.com/2010/01/21/top-ten-philosophical-issues-of-the-21st-century/>.

The College Board. "The Digital Parent Trap 2013 by Time Inc." The Official SAT Study Guide. New York: The College Board, 2016. 620 .

University of Southampton. Philosophy Student Specification. 2013. Accessed: 22 December 2017. $<$ https://www.southampton.ac.uk/philosophy/undergraduate/philosophy_student_specification.page>. 